\title{
Epidemiology of Cutaneous Leishmaniasis, Crimean Congo Hemorrhagic Fever, West Nile Virus and Malaria in Adana Province
}

\author{
Şark Çıbanı, Kırım Kongo Kanamalı Ateși, Batı Nil Virüsü ve \\ Sıtma'nın Adana İlindeki Epidemiyolojisi
}

\author{
Onur Acar¹, Burak Akbaba², Ali Tanju Altunsu³, Yakup Yılancığglu³ \\ 'Çukurova University, Faculty of Medicine' Department of Public Health, Adana \\ ${ }^{2}$ Hacettepe University, Faculty of Science, Department of Biology, Ankara \\ 3Public Health Service Department, Provincial Directorate of Health, Adana
}

\begin{abstract}
Objectives: Aim of this study was to determine the biological and current epidemiological characteristics of some vector-borne diseases including Cutaneous Leishmaniasis (CL), Crimean-Congo Hemorrhagic Fever (CCHF), West Nile Virus (WNV) and Malaria in Adana to provide guidance for employees in public health.

Materials and Methods: This study was carried out in cooperation with Public Health Department of Çukurova University and Public Health Services of Adana Provincial Health Directorate. After the necessary permissions, records of Vectorial and Zoonotic Diseases Unit including approximately 3 years period between 01.01.2016 and 15.11.2018 have been examined. Data were analyzed using STATISTICA 8.0 software and $\chi_{2}$ binary or multiple comparisons were used. $\mathrm{p}<0.05$ was considered significant level.

Results: $86.20 \%$ (n: 550 ) of 638 cases were local cases in which contact with the agent was inside Adana and the rest (n: 88) were import cases. 89.34\% (n: 570) of all cases were belong to CL, followed by Malaria, WNV and CCHF with 5.32\% (n: 34), 2.83\% (n: 18) and 2.51\% (n: 16), respectively. 50,35\% (n: 287) of CL patients were male and the mean age was 23.97 years. Also $54.10 \%$ (n: 317 ) of CL was seen in Syrian migrants. It was found statistically significant that number of CL in Syrian migrants was higher than that of Turkish citizens ( $\mathrm{p}=0.023)$ and higher in January and May than in other months $(\mathrm{p}<0.001)$. The mean age of the cases in CCHF was 35.68 years, $75.00 \%$ (n: 12 ) was male and $6.25 \%$ (n: 1 ) resulted in death. It was found statistically significant that CCHF was seen in June-August period more than the other months ( $\mathrm{p}<0.01$ ). The mean age of WNV was 36.52 years, $88.9 \%$ ( $\mathrm{n}: 16)$ was male, $22.22 \%(\mathrm{n}: 4)$ had WNV-induced neurological disease and 5.55\% (n: 1 ) resulted in death. It was also found that WNV was more common in July and September than in other months ( $\mathrm{p}<0.001)$. The mean age of malaria cases was 38.54 years, $2.94 \%$ (n: 1 ) was foreigners and all (n: 34 ) were males and import cases.

Conclusion: All these diseases are still important today in our country as they have serious health effects. It is a known fact that current epidemiological studies that define the different characteristics of diseases guide the implementation of preventive health services. We hope that the current data on these vector-borne diseases will guide all healthcare providers working in the field.

Key words: Cutaneous Leishmaniasis, Crimean Congo Hemorrhagic Fever, West Nile Virus, malaria, vector-borne, Turkey
\end{abstract}

\section{$\ddot{O} \mathbf{z}$}

Amaç: Çalıșmamızın amacı Adana ilinde Şark Çıbanı, Kırım-Kongo Kanamalı Ateși (KKKA), Batı Nil Virüsü (BNV) ve Sıtma'nın dahil olduğu bazı vektörel hastalıkların biyolojik ve güncel epidemiyolojik özelliklerini tanımlayarak birinci basamak ve halk sağlığı alanında çalıșanlara yol göstermesini sağlamaktır.

Materyal ve Metot: Bu çalışma Çukurova Üniversitesi Halk Sağlığı Anabilim Dalı ve Adana İl Sağlık Müdürlüğü Halk Sağlı̆̆ı Hizmetleri Başkanlığı ile ortaklaşa yapılmıştır. Gerekli izinler alındıktan sonra Adana İl Sağlık Müdürlüğü Halk Sağlığı Hizmetleri Başkanlığı Vektörel ve Zoonotik Hastalıklar Birimi'nin elde ettiği Şark Çıbanı, KKKA, BNV ve Sıtma içeren ve o1.01.2016 ile 15.11.2018 zaman aralığını kapsayan yaklașık 3 yıllık kayıtlar incelenmiștir. Veriler STATISTICA 8.o yazılımı kullanılarak analiz edilmiştir. Verilerin niteliğine göre uygun $\chi^{2}$ ikili veya çoklu karşılaştırma testlerinden yararlanılmıștır. Tüm istatistik analizlerde $\mathrm{p}<0,05$ değeri anlamlı kabul edilmiștir.

Bulgular: Yaklaşık üç yıllık dönemde sık görülen bu dört vektörel hastalıktaki toplam 638 vakanın \%86,20'si (n: 550) etkenle temasın Adana'da olduğu yerel vaka, \%13,8o'i (n: 88) importe vakadır. 
Vakaların \%89,34’ü (n: 570) Şark Çıbanı, \%5,32'si (n: 34) Sitma, \%2,83’ü (n: 18) BNV, \%2,51 (n: 16) KKKA'dır. Şark çıbanında vakaların \%50,35\%i (n: 287) erkek ve yaş ortalaması 23,97 yıldır. Şark çıbanının \%54,1'i (n: 317) Suriyeli göçmenlerde görülmüştür. Şark çıbanının Suriyeli göçmenlerde Türk vatandaşlarına göre daha fazla $(\mathrm{p}=0,023)$ ve Ocak ile Mayıs aralığında, diğer aylara göre daha yüksek sıklıkta görülmesi istatistiksel olarak anlamlı bulunmuştur ( $\mathrm{p}<0,001)$. Kırım Kongo Kanamalı Ateşi'nde vakaların yaș ortalaması 35,68 yıl, \%75,oo’i (n: 12) erkek ve \%6,25'sinin (n: 1) ölüm ile sonuçlandığı görülmektedir. Haziran ile ağustos aralı̆̆ında, diğer aylara göre daha fazla görülmesi istatistiksel olarak anlamlı bulunmuștur (p<0,01). BNV'de yaș ortalaması 36,52 yıl, \%88,9'u (n: 16) erkek, \%22,22'sinde (n: 4) BNV kaynaklı nörolojik hastalık görülmüș ve \%5,55'sı da (n: 1) ölümle sonuçlanmıștır. BNV'nin temmuz ile eylül aralığında diğer aylara göre daha fazla görüldüğü istatistiksel olarak anlamlı bulunmuștur (p<0,0o1). Sitma vakalarının yaș ortalaması 38,54 yıl, \%2,94'ü (n: 1) yabancı uyruklu ve tamamı (n: 34 ) erkek ve importe vakadır.

Sonuç: Şark Çıbanı, KKKA, BNV ve Sıtma tüm dünyada olduğu gibi ülkemizde de ciddi sağlık etkileri olması bakımından günümüzde hala önemini korumaktadır. Hastalıkların farklı özelliklerini tanımlayan güncel epidemiyolojik çalıșmaların, koruyucu sağlık hizmetlerinin uygulanmasına rehberlik ettiği bilinen bir gerçektir. Çalıșmamızda yer alan bu vektörel hastalıklarla ilgili güncel verilerin, alanda çalışan tüm sağlık sunucularına yol göstereceğini umuyoruz.

Anahtar kelimeler: Șark çıbanı, Kırım-Kongo Kanamalı Ateși, Batı Nil virüsü, sıtma, vektörel, Türkiye

\section{Correspondence / Yazıșma Adresi:}

Dr. Onur Acar

Çukurova University, Faculty of Medicine' Department of Public Health, Balcalı/Sarıçam, Adana

e-mail: dronuracar@yandex.com

Date of submission: 24.11 .2018

Date of admission: 06.12.2018

\section{Introduction}

Vector-borne diseases are serious public health problems that maintain their importance worldwide. They are responsible for $17 \%$ of all infectious diseases and causes approximately 700.000 deaths. ${ }^{1}$

Vector-borne diseases are infections transmitted by the bite of infected arthropod species, such as mosquitoes, ticks, triatomine bugs, sandflies, and blackflies. ${ }^{2}$

The distribution of vector-borne disease is determined by many factors; demographic, environmental and social. In addition, some problems such as increasing global travel and trade, unplanned urbanization, climate change, changes in human populations, landscape, land use and agricultural practices that occur today affect many areas as they also affect the prevalence and distribution of vector-borne diseases.3,4

Arthropod vectors are ectothermic animals and thus especially sensitive to climatic factors. Weather influences survival and reproduction rates of vectors. ${ }^{5}$

Vector-borne diseases, especially in tropical and sub-tropical regions, often affect the population living in poor conditions in underdeveloped countries. ${ }^{6}$ However, it has the potential to seriously affect the developed countries due to different situations.

These diseases are particularly prevalent in the rural areas practicing with agriculture and animal husbandry but can also be seen as nosocomial infections. Nosocomial infections occur as nonvector-mediated transmission in healthcare workers. The risk of nosocomial transmission with lethal potential should not be ignored and protective measures should be taken during service delivery. ${ }^{7-9}$

In our country, vector-borne diseases such as Cutaneous Leishmaniasis (CL), CrimeanCongo Hemorrhagic Fever (CCHF), West Nile Virus (WNV) and Malaria are important 
as they are in the world. These diseases cause periodic outbreaks, threaten public health, and put the country's economy into a difficult situation. For this reason, it is very important to continue the studies related to these diseases and to publish the current situation in different regions of our country.

In this study, we aimed to determine the biological and current epidemiological characteristics of some vector-borne diseases including Cutaneous Leishmaniasis (CL), Crimean-Congo Hemorrhagic Fever (CCHF), West Nile Virus (WNV) and Malaria in Adana to provide guidance for employees in public health.

\section{Materials and Methods}

This study was carried out in cooperation with the Public Health Department of Çukurova University and Public Health Services of Adana Provincial Health Directorate. Legal permissions required for the study were provided by Adana Provincial Directorate of Health (No: 60247264- 044) and the ethics committee permission was provided by Ankara Yıldırım Beyazit University Ethics Board (No: 2018351). CL, CCHF, WNV and Malaria records of Vectorial and Zoonotic Diseases Unit including approximately three years period between 01.01.2016 and 15.11.2018 were examined after necessary permissions. CL, CCHF, WNV and Malaria cases, which were diagnosed only in health institutions in Adana province, were used in the analysis phase. Differences between age, sex and nationality classes, origin of the cases (import or local to Adana), differences between years and months, the incidence of cases between the districts and between urban and rural areas of Adana were evaluated in this study. The central districts of Adana (Seyhan, Yüreğir, Çukurova, Sarıçam and Karaisalı) were considered as urban areas and other 10 districts (Aladağ, Ceyhan, Feke, İmamoğlu, Karataş, Kozan, Pozantı, Saimbeyli, Tufanbeyli, Yumurtalık) as rural areas for the analyses. Excel Power Pivot was used for data editing, tables and graphics. Data were analyzed using STATISTICA 8.o software and $\chi^{2}$ binary or multiple comparisons have been applied. We used an alpha $(\alpha)$ value of 0.05 as our significance level for all comparisons.

\section{Results}

A total of 638 cases were observed in four vector-borne diseases examined in Adana province from the beginning of 2016 till November 2018. 86.20\% ( $n: 550$ ) of these cases were local cases in which contact with the agent was inside Adana. On the other hand, $13.80 \%(n: 88)$ were import cases where the contact with the agent was outside, however its diagnosis, notification or treatment was performed inside Adana. Of 638 vectorial cases, the most common disease was CL with a rate of $89.34 \%$ (n: 570; Figure 1).

\section{Cutaneous Leishmaniasis}

It was determined that the mean age of 570 local and import CL cases in observation period was 23.97 years (median: 18, max: 89, SD: 19.53; Table 1). 50.35\% (n: 287) of these cases were male and $49.65 \%$ (n: 283 ) were female. It was remarkable that CL was more likely to be seen in foreign nationals ( $54.74 \%$ of all CL cases; $\left.\chi^{2}=5.115, \mathrm{p}=0.023\right)$.

91.75\% (n: 523) of all CL cases were local and the remaining 8.25\% (n: 47 ) were import. Evaluation of CL cases in terms of districts of Adana showed that the disease was concentrated in Seyhan (29.64\%, n: 169), Yüreğir (24.56\%, n: 140) and Sarıçam (11.57\%, 
Epidemiology of Cutaneous Leishmaniasis, Crimean Congo Hemorrhagic Fever, West Nile Virus and Malaria in Adana Province

n: 66) districts (Figure 2). In terms of urban and rural areas, $79.16 \%$ (n: 414) of all cases were observed in urban and 20.84\% (n: 109) were observed in rural areas and this difference was statistically significant $\left(\chi^{2}=177.868, \mathrm{p}<0.001\right)$.

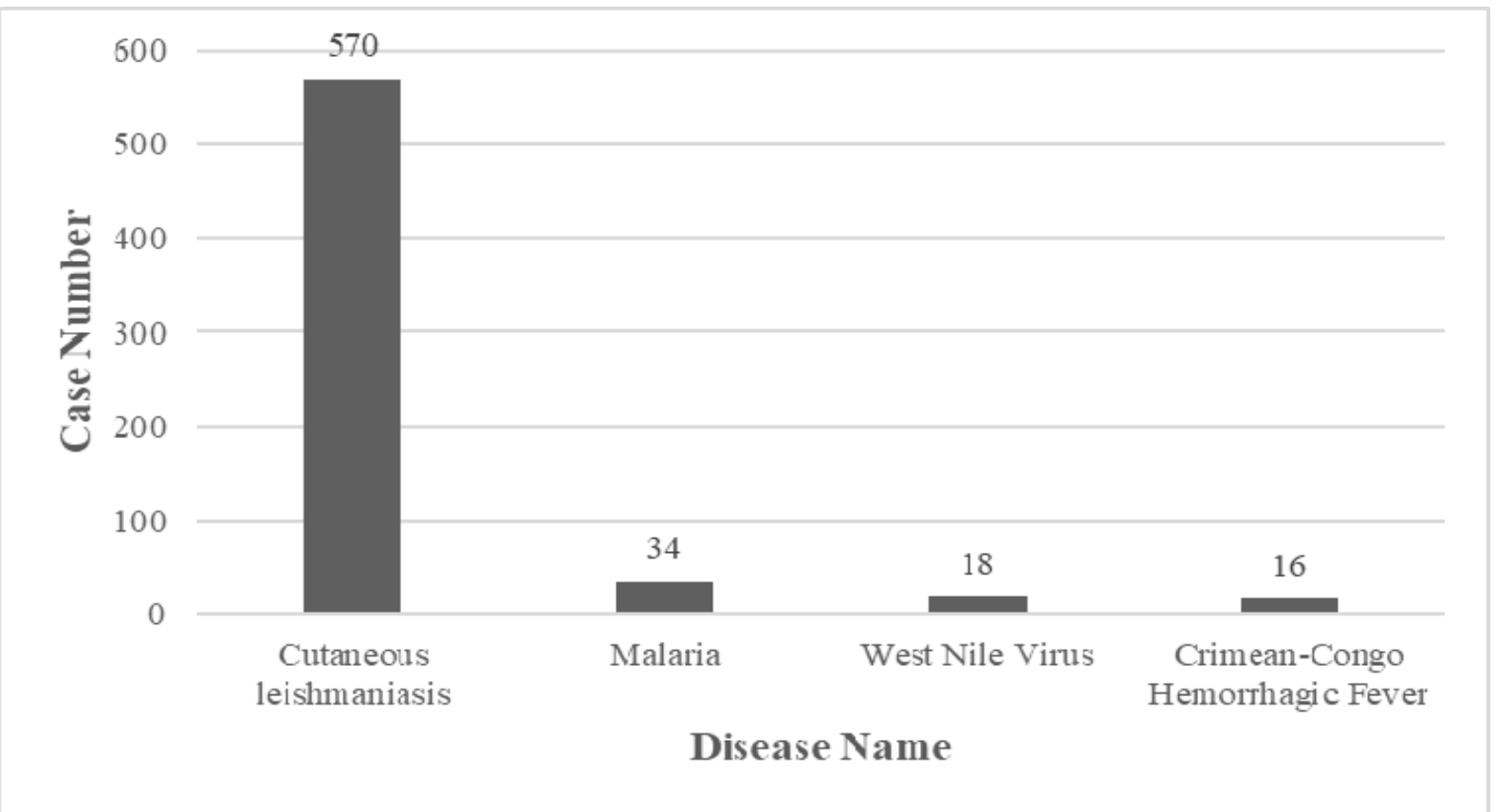

Figure 1. General Case Distribution, 2016-2018, Adana

The cases were observed higher in January and May than in September and December $\left(\chi^{2}=144.021, p<0.001\right.$; Figure 3 ). In terms of years, 39.12\% ( $\left.\mathrm{n}: 223\right)$ of cases were observed in 2016, 29.47\% (n: 168) in 2017 and 31.40\% (n: 179) in 2018.

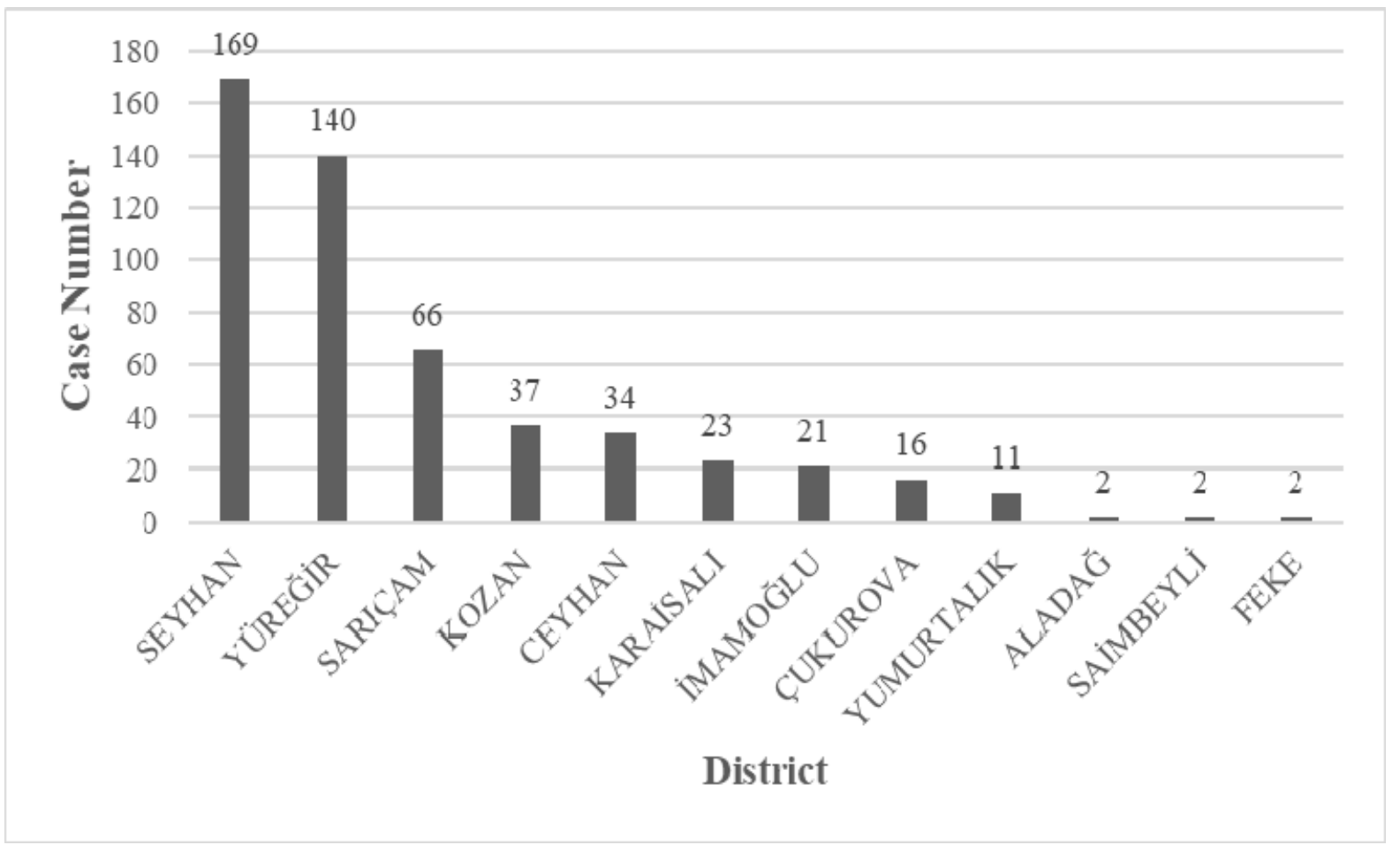

Figure 2. Geographic Distribution of CL in Adana 


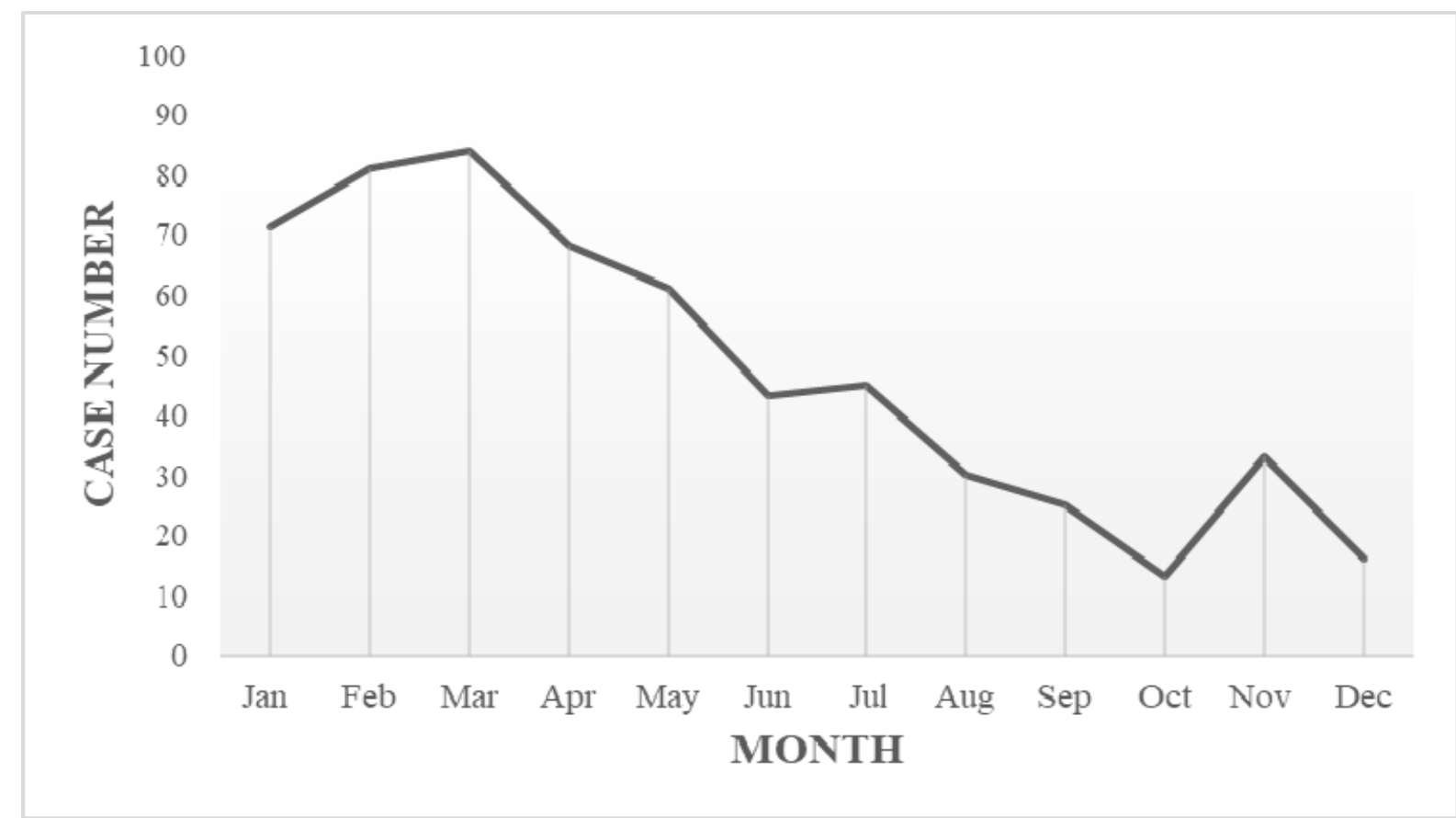

Figure 3. Monthly Distribution of CL in 3 years period

\section{Crimean-Congo Hemorrhagic Fever}

It was determined that the mean age of $16 \mathrm{CCHF}$ cases in observation period was 35.68 years (median: 22, max: 83, SD: 27.44; Table 1). $75.00 \%$ (n: 12) of these cases were male and $25.00 \%$ ( $n: 4$ ) were female. $6.25 \%$ ( $n: 1$ ) of these cases were foreign nationals. When the prognosis was examined, $6.25 \%$ of the cases (n: 1 ) resulted in death.

Of the 16 cases, $75.00 \%$ (n: 12 ) were local cases and the remaining $25.00 \%$ (n: 4 ) were import. Among local cases, 5 of them were observed in Saimbeyli and 1 in Feke, Tufanbeyli, Seyhan, Kozan, Yüreğir, Ceyhan and Sarıçam. The difference between the incidence of cases in urban and rural areas was not statistically significant (urban n: 3 , rural $\mathrm{n}$ : $9 ; \chi^{2}=3.000, \mathrm{p}=0.083$ ).

CCHF started in March, peaked in July, and ended in September. It was more common in June to August than in other months $\left(\chi^{2}=41.102\right.$, $p<0.001$; Figure 4$)$. In terms of years, $62.50 \%$ (n: 10) of the cases were observed in 2016 and 18.75\% (n:3) in 2017 and 2018.

\section{West Nile Virus}

The mean age of $18 \mathrm{WNV}$ cases was 36.52 years (median: 32, max: 75, SD: 22.58; Table 1) $88.89 \%$ (n: 16$)$ of the cases were male and the rest were female. $5.55 \%(n: 1)$ of all cases resulted in death. WNV-induced neurological disease was observed in $22.22 \%$ (n: 4 ) of the patients.

On the other hand, $83.33 \%$ (n: 15) were local cases and $16.67 \%$ (n:3) were import. Among local cases, there were 4 cases in Yüreğir, 3 in Seyhan and Ceyhan, 2 in Sarıçam, 1 in İmamoğlu, Çukurova and Yumurtalık. No statistically significant difference was found between the rural and urban areas $\left(\chi^{2}=1.667, p=0.196\right)$. 
Epidemiology of Cutaneous Leishmaniasis, Crimean Congo Hemorrhagic Fever, West Nile Virus and Malaria in Adana Province

WNV were more common between July and September than in other months $\left(\chi^{2}=67.333, p<0.001\right.$; Figure 5). $11.11 \%$ (n: 2$)$ of the cases were observed in $2016,22.22 \%$ $(\mathrm{n}: 4)$ in 2017 and $66.66 \%$ (n: 12) in 2018.

Table 1. Age and sex distributions of CL, CCHF, WNV and Malaria cases in Adana province in three-year study period

\begin{tabular}{|l|l|c|c|c|c|c|c|}
\hline \multirow{2}{*}{ Disease } & \multirow{2}{*}{ Sex } & \multicolumn{7}{|c|}{ Age } \\
\cline { 3 - 8 } & & $\mathbf{n}(\%)$ & Mean & Median & Max & $\begin{array}{c}\text { Std. } \\
\text { Dev. }\end{array}$ & $\begin{array}{c}\text { Std. } \\
\text { Err. }\end{array}$ \\
\hline \multirow{3}{*}{$\begin{array}{l}\text { Cutaneous } \\
\text { leishmaniasis }\end{array}$} & Male & $287(50.35 \%)$ & 23.50 & 18 & 79 & 18.53 & 1.09 \\
\cline { 2 - 9 } & Female & $283(49.65 \%)$ & 24.46 & 17 & 89 & 20.52 & 1.22 \\
\cline { 2 - 9 } & Total & $570(100.00 \%)$ & 23.97 & 18 & 89 & 19.53 & 0.82 \\
\hline \multirow{3}{*}{$\begin{array}{l}\text { Crimean-Congo } \\
\text { Hemorrhagic Fever }\end{array}$} & Male & $12(75.00 \%)$ & 39.68 & 29 & 83 & 28.23 & 8.15 \\
\cline { 2 - 9 } & Female & $4(25.00 \%)$ & 23.70 & 16 & 57 & 24.26 & 12.13 \\
\cline { 2 - 9 } & Total & $16(100.00 \%)$ & 35.68 & 22 & 83 & 27.44 & 6.86 \\
\hline \multirow{3}{*}{$\begin{array}{l}\text { West Nile Virus } \\
\text { Malaria }\end{array}$} & Male & $16(88.89 \%)$ & 36.45 & 32 & 75 & 23.20 & 5.80 \\
\cline { 2 - 9 } & Female & $2(11.11 \%)$ & 37.07 & 37 & 54 & 24.41 & 17.26 \\
\cline { 2 - 9 } & Total & $18(100.00 \%)$ & 36.52 & 32 & 75 & 22.58 & 5.32 \\
\hline & Male & $34(100.00 \%)$ & 38.54 & 36 & 59 & 9.98 & 1.71 \\
\cline { 2 - 9 } & Female & $0(0.00 \%)$ & - & - & - & - & - \\
\cline { 2 - 9 } & Total & $34(100.00 \%)$ & 38.54 & 36 & 59 & 9.98 & 1.71 \\
\hline
\end{tabular}

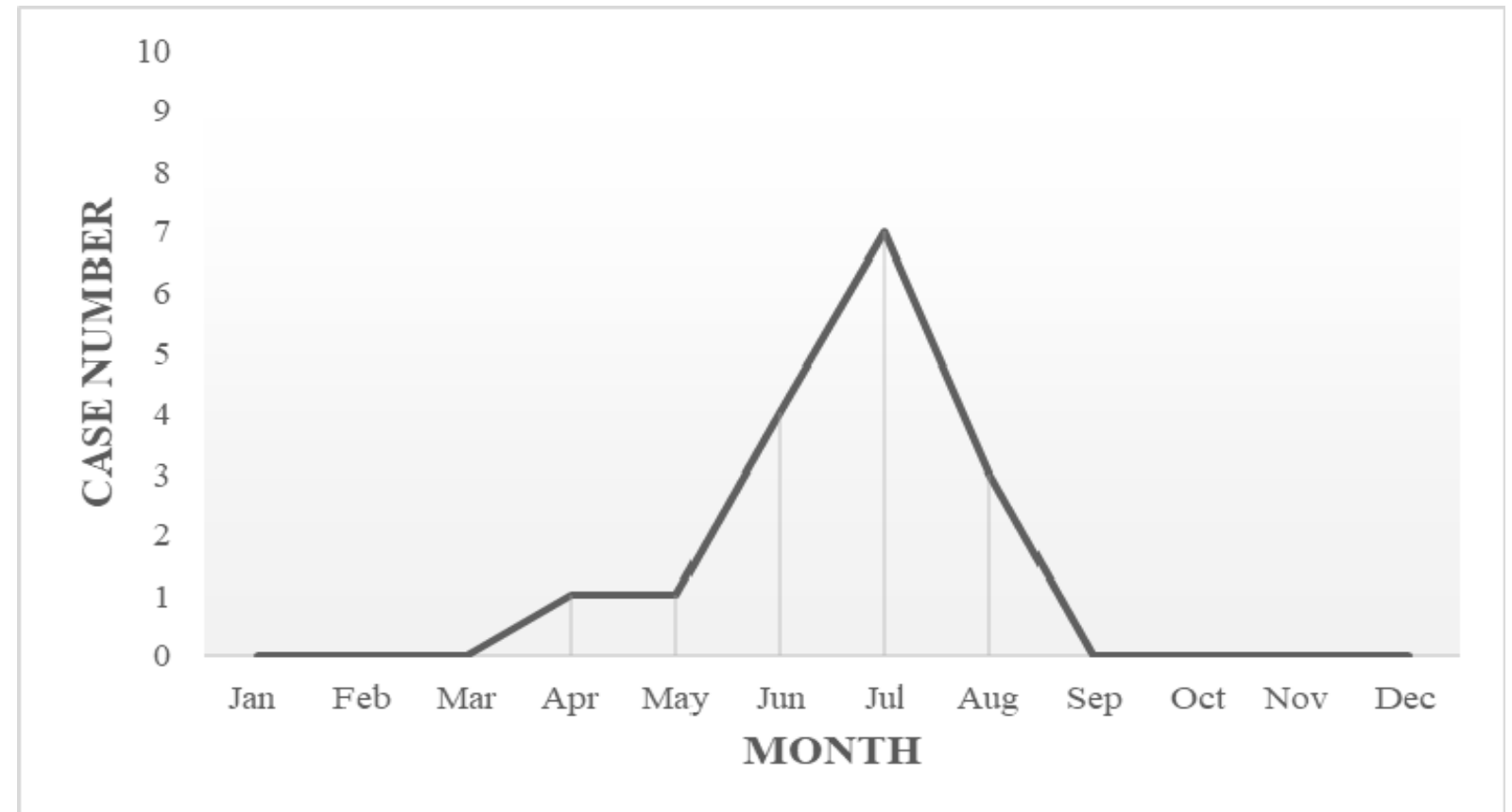

Figure 4. Monthly distribution of CCHF in 3 years period 


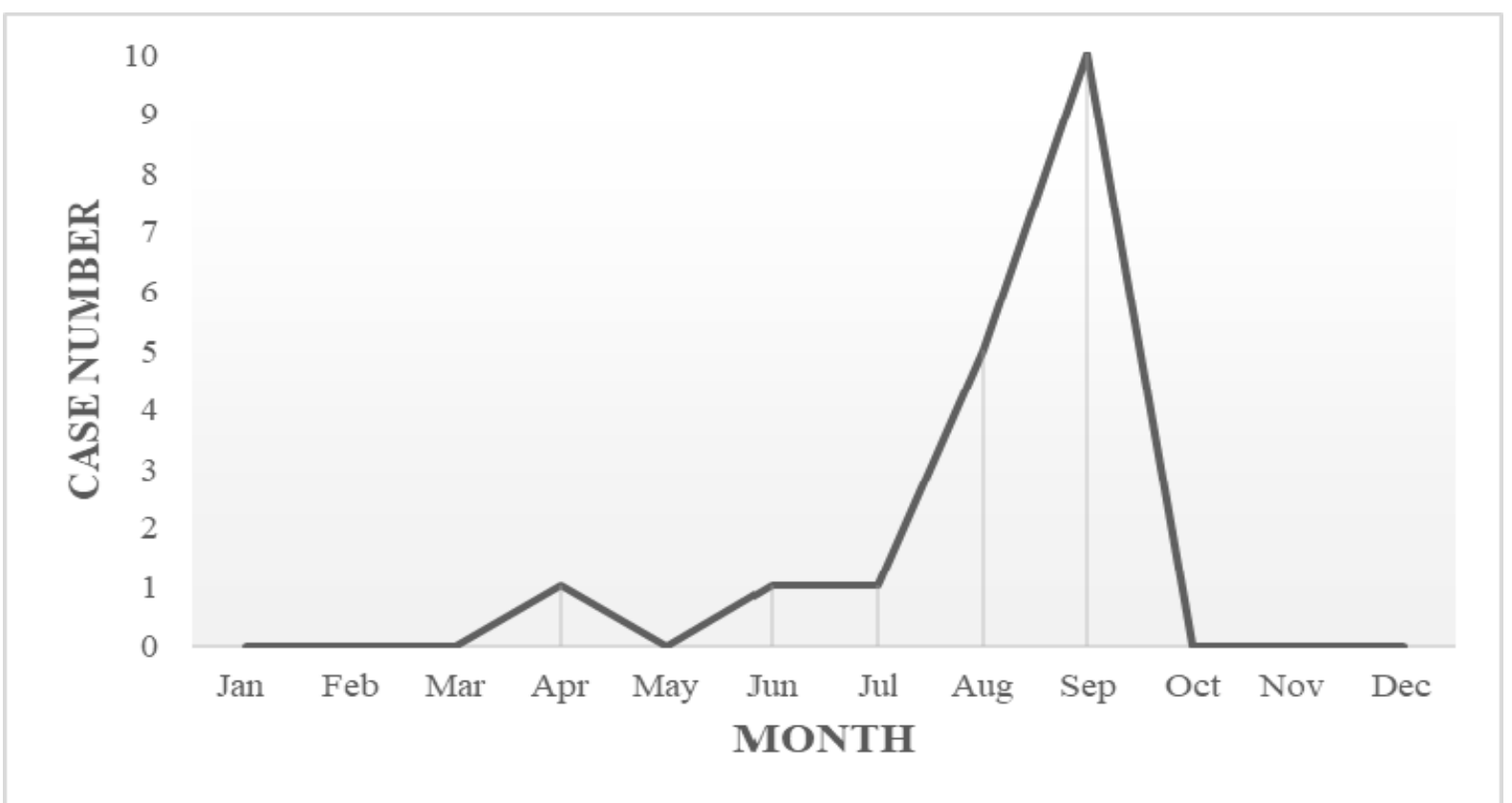

Figure 5. Monthly distribution of WNV in 3 years period

\section{Malaria}

It was determined that the mean age of 34 malaria cases in observation period was 38.54 years (median: 36 , max: 59, SD: 9.98; Table 1). All the cases were male (n: 34 ) and 2.94\% (n: 1) of them were foreign nationals.

All cases were imported meaning to have taken the causative agent in African countries or have received Malaria treatment in African countries and had the disease in our city again. None of the cases has resulted in death.

Although malaria cases were seen in high rates between May and September, this was not statistically significant $\left(\chi^{2}=10.48297, \mathrm{p}=0.487\right.$; Figure 6$)$. In terms of years, $20.60 \%$ (n: 7) of all cases were seen in 2016, 32.35\% (n: 11) in 2017 and 47.05\% (n: 16) in 2018.

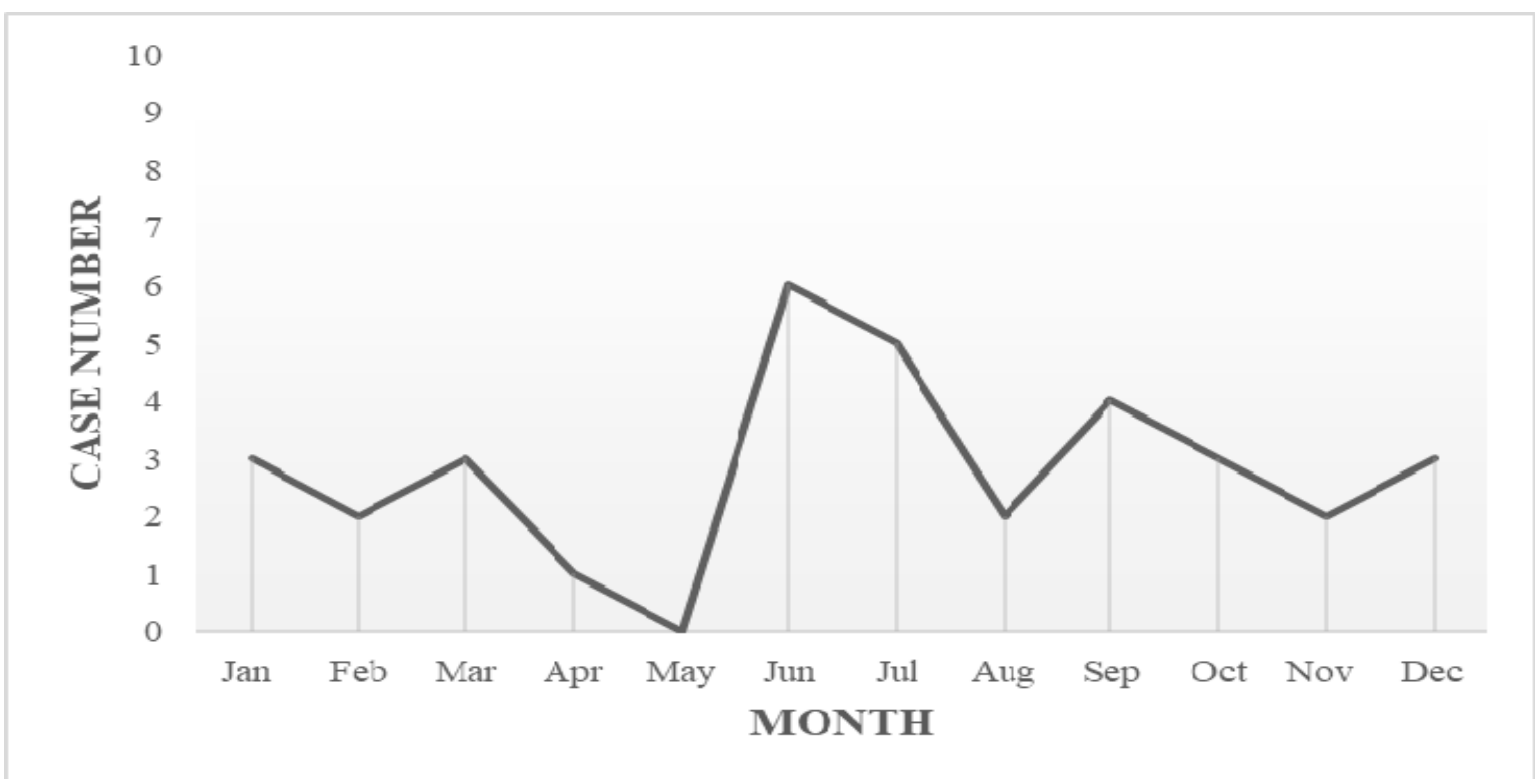

Figure 6. Monthly distribution of Malaria in 3 years period 
Epidemiology of Cutaneous Leishmaniasis, Crimean Congo Hemorrhagic Fever, West Nile Virus and Malaria in Adana Province

\section{Discussion}

\section{Cutaneous Leishmaniasis}

In our study, $50.35 \%$ of the cases were male and the mean age was 23.97 years. In an eight-year period study in Antalya ${ }^{10}, 56.60 \%$ of the cases and in a cross-sectional study with two thousand people in $\operatorname{Iran}^{11}$, $55.20 \%$ of the cases were male. In a study conducted in Diyarbakır, $55.50 \%$ of the cases were female, and the mean age was 19.4 years $^{12}$, on the other hand, in a study conducted in Çukurova region, $55.00 \%$ of the cases were female and the mean age was 30.70 years. ${ }^{13}$ The age and gender distribution of CL does not show a homogeneous distribution in the literature and the results are different from our study.

In our study, $54.74 \%$ of the cases were foreign nationals. All of these cases consist of Syrian migrants who are under temporary protection. Dense population of Temporary Protected Syrians (TPS) inhabits southern provinces of Turkey that are neighboring Syria. Adana is the fifth largest city in Turkey hosting TPS population $(6.3 \%, \mathrm{n}$ : 227,066). ${ }^{14}$ The fact that more than half of the cases are from the migrant population shows there are serious health risks coming with the migration. This situation demonstrates the importance of regular screening and preventive studies for vectorborne diseases in both temporary shelter centers and in the southern provinces where Syrian population is densely populated.

On the other hand, in our study, it was seen that the cases were more frequent in January and May than in September and December, and this difference was statistically significant $(\mathrm{p}<\mathrm{0.001})$. In a study conducted in Hatay, it was observed that the cases were concentrated in May and June. ${ }^{15}$ However, Uzun et al. ${ }^{16}$ and Ok et al. ${ }^{17}$ in two separate studies showed the cases were observed mostly in October, November and December. When the distribution of CL cases is examined according to months and seasons, it is seen that they are mostly reported in spring and at least in autumn months. This may be caused by the presence of hot and humid air, which are suitable conditions for the reproduction of the mosquito, at different times between different regions and the emergence of the disease after 2 to 6 months after the mosquito carrying the causative agent infects the human.

\section{Crimean-Congo Hemorrhagic Fever}

In our study, $75.00 \%$ of the cases were male and the mean age was 35.68 years. It is known that the majority of cases are concentrated in men in accordance with our study. Yilmaz et al. ${ }^{18}$ conducted a study througout Turkey, between 2002 and 2007 and showed that $53 \%$ of the cases were male and the mean age was 44 years. Ince et al. ${ }^{19}$ reported that $67 \%$ were male of all cases in their study. Sharififard et al. conducted two different studies in Iran and reported in their study, which was between 1999 and 2015 that $53 \%$ of all cases were male. ${ }^{20}$ In their other study throughout 23 provinces in Iran over a ten-year period, $77.5 \%$ of all cases were male and more than half $(52.2 \%)$ were between $21-40$ years of age. ${ }^{21}$ In an other study conducted in Kastamonu, $56 \%$ of the cases were also found to be female and the mean age was 52 years. ${ }^{22}$ 
Since the population of young people under the age of 30 migrates to cities, male population in rural areas is the majority of the labor force in agriculture and animal husbandry. This situation is thought to increase the risk of disease in men.

In our study, the rate of fatality was $6.25 \%$ (n: 1 ). Yilmaz et al. ${ }^{18}$ was stated that the average rate of fatality was $5 \%$ and this rate was evaluated as $4.67 \%$ according to the data of Ministry of Health between 2008-2017. İnce et al. ${ }^{19}$ reported that fatality rate was $13 \%$ in worldwide and $10 \%$ in Turkey. Sharififard et al. found a high rate of fatality in their study (28.6\%). In some regions, the rate of fatality could reach up to $80 \%{ }^{23-25}$

Fetal rate of CCHF has differences according to regions. Due to the difficulties in accessing health services and lack of awareness about the disease due to geographical characteristics, delay in diagnosis and treatment is thought to lead to different rates of fatalities.

In our study, although the cases were concentrated in rural areas, the difference between urban and rural areas was not statistically significant ( $\mathrm{p}=0.083)$. CCHF cases are known to concentrate on the rural population, in particular the population that subsists on agriculture. However, in the literature, it is possible to see different results that vary according to regions.

A study in $\operatorname{Iran}^{26}$ reported that $66.70 \%$ of the cases were in rural areas, but another study also in Iran ${ }^{20}$ reported that $64.3 \%$ of cases were observed in urban areas.

It is stated that the cases started to increase in March in the northern hemisphere and peaked in June and July. ${ }^{21,27}$ In our study, the results of the seasonal situation were in accordance with the literature. Ticks are more active in the spring and summer months, and agriculture and livestock activities concentrate in the same period. These factors lead to seasonal differences of CCHF cases.

\section{West Nile Virus}

In our study, the mean age of the cases was 36.52 years. In another study also conducted in Turkey with 438 volunteer blood donor the mean age was $34 \cdot 7 \cdot{ }^{28}$ The average age of the 47 cases is reported to be 58 years in a study conducted in 2010 in Turkey. ${ }^{29}$ and in Italy in 2013 in other study, this mean age was found to be 73 years. ${ }^{30}$ In the literature, there are different results that are not close to each other in terms of age.

In our study, $88.89 \%$ of the cases were male and our findings are in accordance with the literature. Napoli et al. ${ }^{30}$ reported $61.30 \%$ of the cases, Kalaycıoğlu et al. ${ }^{29}$ reported $68.10 \%$ of the cases and Biçeroğlu et al. ${ }^{28}$ reported $92.24 \%$ of the cases were male. Also in a study with $3145 \mathrm{WNV}$ cases in Israel between 2011 and 2014, 51.60\% of the cases found to be male ${ }^{31}$. Most probably, the fact that males travel more to endemic regions leads to this situation.

In our study, the fatality rate of cases was $5.55 \%$. European Center for Disease Protection and Control (ECDC) stated that in 2017, 26 of 204 cases in EU region resulted in death and the disease's fatality rate was $9 \%$. In the same text it was also mentioned that 1 of 7 cases resulted in death in Turkey in 2017. ${ }^{32}$ In our country, 10 of 47 cases between 2010-2011 resulted in death and the rate of fatality was reported to be $21 \% .{ }^{29}$ In general, $70-80 \%$ of the patients have no clinical symptoms. In only $1 \%$ of those with clinical symptoms (elderly, children, pregnant and immunocompromised 
groups such as HIV / AIDS patients), the disease is fatal. Fatalitic speed is different in the studies is due to the difference between the regions at above-mentioned risk groups.

ECDC reported that 50 of 2873 WNV cases (1.74\%) observed in Eastern Europe between the years 2010-2016 was in Turkey. It was stated that there were 47 cases in 2010, 3 cases in 2011, but no cases between 2012 and 2016 were observed. 2 of 7 cases observed in Turkey in 2017 was in Adana. 33 In the same time period, vast majority of cases were observed in Turkey's neighbor countries Russia and Greece (1464 in Russia and 545 cases in Greece) shows that Turkey is at serious risk of the disease. From the beginning of 2018 to 18 October, 1436 WNV cases were observed in EU member states and 162 cases resulted in death. ${ }^{34}$ It is important to make disease surveillance more effective..$^{30}$

In our study, the cases were more prevalent in August-September than in other months and this difference was statistically significant $(\mathrm{p}<0.001)$. In a study conducted in Italy, cases occurred between July and September and $75.00 \%$ of the symptoms started in August and peaked in this month..$^{30}$ In another study conducted in Eastern European countries, the cases were reported to be more frequent in August. ${ }^{35}$ In the cycle of the disease, mosquitoes are often transmitted by migratory birds taking the cause in Africa. After that mosquitoes infects humans and horses. The concentration of cases in the summer months is attributed to this migration pattern in the cycle.

\section{Malaria}

The mean age of our study was 38.54 years. Yentur Doni et al..$^{6}$ examined 11 years' cases between 2001 and 2011 in Şanliurfa and reported that the mean age was 19.21 years. Aydın et al. ${ }^{37}$ reported the cases are between 15 and 49 years of age in Mersin. In another study conducted in Iran, the mean age was 31.57 years and the cases were between 31 and 40 years (51.13\%, n: 68). $3^{8}$

In our study, all cases were male. In our country different studies in Şanlıurfa (53.45\%), ${ }^{36}$ Adana (58.70\%), ${ }^{39}$ Mersin (6o.27\%), ${ }^{37}$ and Antalya (74\%) ${ }^{40}$ reported that the disease is more common in men. In two different studies conducted in Iran, the incidence of cases in men was $77.60 \%{ }^{41}$ and $86.46 \% .{ }^{38}$ Until 20oos, malaria was more endemic in the southern regions of our country, especially in the male population dealing with agriculture. In the last decade, however, endemic cases have been replaced by import cases, mostly males traveling to African countries. This is thought to be the reason for the concentration of cases in male population.

In our study, all cases were imported meaning to have taken the causative agent in African countries or have received Malaria treatment in African countries and had the disease in our city again. In our country, studies conducted up to ten years ago indicate that local cases were high ( $70 \%$ to $80 \%$ in range). ${ }^{36,37,40}$ But today Turkey is not an endemic region and most of the cases are observed as an import case. Karadağ et al. ${ }^{42}$ reported in their study that all cases were import cases caused by travel to African countries.

When the definitive diagnoses in our study were examined, it was determined that $70.60 \%$ (n: 24 ) of the 34 cases found to be caused by Plasmodium falciparum, $20.58 \%$ (n: 7) caused by $P$. vivax and $8.82 \%$ (n: 3 ) caused by both and called as mixed type. 
Karadağ et al..$^{42}$ in 13 -year trial in Samsun, reported $87.5 \%$ of the cases were caused by P. falciparum.

In our country it was found in different studies that most of the cases were $P$. vivax type in Şanlıurfa (99.9\%), ${ }^{6}$ Adana (90.90\%), ${ }^{39}$ Mersin (91.78), 37 Antalya (86\%)..${ }^{40}$ In two different studies conducted in Iran, the rate of $P$. vivax in cases was reported as $94.92 \%{ }^{43}$ and $83.00 \%{ }^{41}$ and it was found to be high. In our country, $P$. vivax was frequently seen when the disease was endemic. However, since the import cases from African countries mostly carry $P$. falciparum type, the effect of this condition appears in our study.

In our study, malaria cases were concentrated between May and September in accordance with the literature. In our country, there are many studies showing that the number of Malaria cases were the highest in Şanlıurfa and Antalya between May and November, ${ }^{36,40}$ Adana and Mersin between June and September. ${ }^{39,37}$ In Iran, there are studies showing that the cases were mostly between June-October ${ }^{38}$ and between April and November. ${ }^{43}$ Hot and humid zones have suitable conditions for the reproduction and spread of mosquitoes. It is thought that the cases intensified in May-September due to travel to endemic countries during these months when weather conditions are appropriate.

CL, CCHF, WNV and Malaria are still important today in terms of serious health effects in our country as well as all over the world. Vector-borne diseases cause outbreaks and affect a large part of society. Current epidemiological studies that define the individual, place, time and different characteristics of diseases provide significant benefits to the studies conducted to prevent outbreaks and health effects. Increasing the knowledge and awareness of all health workers, especially the physicians working in preventive health services, in terms of vector-borne diseases is of great importance for the protection of public health.

In the months when these diseases are seen frequently, taking personal and environmental measures reduces the risk. For this purpose, it is very important to provide health education to the society at risk about protection from vector diseases. Brief information about diseases should be given in health education, ways of personal protection should be explained and people should be informed about in which conditions they should consult to the relevant health institutions. These educations should continue regularly.

\section{References}

1. World Health Organization [Internet]. Vector-borne diseases. Available from: http://www.who.int/news-room/fact-sheets/detail/vector-borne-diseases , Date of Access: October 15, 2018.

2. European Centre for Disease Prevention and Control [Internet]. Vector-borne diseases. Available from: https://ecdc.europa.eu/en/climate-change/climate-change-europe/vectorborne-diseases , Date of Access: October 15, 2018.

3. Kilpatrick AM, Randolph SE. Drivers, Dynamics, and control of emerging vector-borne zoonotic diseases. Lancet 2012;380(9857):1946-55.

4. Reiter P. Climate change and mosquito-borne disease. Environ Health Perspect 2001; 109(Suppl 1):141-61.

5. Rogers DJ, Randolph SE. Climate change and vector-borne diseases. Adv Parasitol 2006;62:34581 . 
Epidemiology of Cutaneous Leishmaniasis, Crimean Congo Hemorrhagic Fever, West Nile Virus and Malaria in Adana Province

6. Vector-borne diseases Report of an informal expert consultation SEARO, New Delhi, 7-8 April 2014. World Health Organization 2014. Available from:

http://apps.who.int/iris/bitstream/handle/10665/206531/B5139.pdf?sequence=1\&isAllowed =y, Date of Access: October 15, 2018.

7. Aradaib IE, Erickson BR, Mustafa ME et al. Nosocomial outbreak of Crimean-Congo hemorrhagic fever, Sudan. Emerg Infect Dis 2010;16(5):837-39.

8. Chen LH, Wilson ME. Nosocomial Dengue by mucocutaneous transmission. Emerg Infect Dis. 2005;11(5):775.

9. Gruell H, Hamacher L, Jennissen V et al. On taking a diffirent route: An unlikely case of Malaria by nosocomial transmission. Clin Infect Dis 2017;65(8):1404-06.

10. Ser O, Cetin H. Cutaneous leishmaniasis and its status in Antalya, Turkey. Turkish J Parasitology 2013;37(2):84-91.

11. Khosravi A, Sharifi I, Fekri A et al. Clinical features of anthroponotic cutaneous leishmaniasis in a major focus, Southeastern Iran, 1994-2014. Iran J Parasitol 2017;12 (4):544-53.

12. Sucaklı MB, Saka G. Epidemiology of cutaneous leishmaniasis in Diyarbakir, 2002-2006. Turkish J Parasitology 2007:31 (3):165-9.

13. Atakan E, Akbaba M, Sütoluk Z, Alptekın D, Demırhındı H, Uludağ SK. Population density of phlebotomus (Diphtera; Psychodidae; Phlebotomine) species and their relationship with cutaneous leishmaniasis in Hocallı and Turunçlu villages (Adana). Turkish J Parasitology 2010;34(2):106-11.

14. Ministry of İnterior Directorate General of Migration Management [İnternet]. Statistics of Temporary Protection. Available from: http://www.goc.gov.tr/icerik6/temporaryprotection 91510244748 icerik, Date of Access: October 22, 2018.

15. Culha G, Akcali C. Detection of cutaneous leishmaniasis cases in Hatay and surrounding areas. Turkish J Parasitology 2006;30(4):268-71.

16. Uzun S, Uslular C, Yucel A, Acar MA, Ozpoyraz M, Memisoglu HR. Cutaneous leishmaniasis: Evaluation of 3,074 cases in the Cukurova region of Turkey. British J Dermatology 1999;140(2):347-50.

17. Ok UZ, Balcioglu IC, Taylan Ozkan A, Ozensoy S, Ozbel Y. Leishmaniasis in Turkey. Acta Tropica 2002;84(1):43-8.

18. Yilmaz GR, Buzgan T, Irmak $\mathrm{H}$ et al. The epidemiology of Crimean- Congo hemorrhagic fever in Turkey, 2002- 2007. Int J Infect Dis. 2009;13(3):380-6.

19. Ince $Y$, Yasa $C$, Metin $M$ et al. Crimean- Congo hemorrhagic fever infections reported by ProMED. Int J Infect Dis 2014;26:44-6.

20. Sharififard M, Alavi SM, Salmanzadeh S, Safdari F, Kamali A. Epidemiological survey of Crimean- Congo hemorrhagic fever (CCHF), a fatal infectious disease in Khuzestan province, Southwest Iran, during 1999- 2015. Jundishapur J Microbiol 2016;9(5):e30883.

21. Chinikar S, Ghiasi SM, Moradi M et al. Geographical distribution and surveillance of CrimeanCongo hemorrhagic fever in Iran. Vector Borne Zoonotic Dis. 2010;10(7):705-8.

22. Aker S, Akıncı H, Kılıçoğlu C, Leblebicioglu H. The geographic distribution of cases of CrimeanCongo hemorrhagic fever: Kastamonu, Turkey. Ticks Tick Borne Dis 2015;6(6):730- 6.

23. Swanepoel R, Struthers JK, Shepherd AJ, McGillivray GM, Nel Mj, Jupp PG. Am J Trop Med Hyg. 1983;32(6):1407-15.

24. Ergönül O. Crimean-Congo hemorrhagic fever. Lancet Infect Dis 2006;6(4):203-14.

25. Fisher-Hoch SP, McCormick JB, Swanepoel R, Van Middlekoop A, Harvey S, Kustner HG. Risk of human infections with Crimean-Congo hemorrhagic fever virüs in a South African rural community. Am J Trop Med Hyg 1992;47(3):337-45.

26. Izadi S, Naieni KH, Madjdzadeh SR, Nadim A. Crimean-Congo hemorrhagic fever in Sistan and Baluchestan province of Iran, a case-control study on epidemiological characteristics. Int J Infect Dis 2004;8(5):299-306.

27. Türk Tabipleri Birliği Merkez Konseyi. Türk Tabipleri Birliği Kırım Kongo Kanamalı Ateși Bilimsel Değerlendirme Raporu. 1.Baskı, Ankara: Türk Tabipleri Birliği Yayınları; 2010. Available from: https://www.ttb.org.tr/kutuphane/kirim_kongo_rpr.pdf Date of Access: October 23, 2018.

28. Biçeroğlu SU, Karatayli E, Bayram A et al. Investigation of West Nile virus among healthy blood donors in the western part of Turkey. Turk J Med Sci 2015;45(1):84-8.

29. Kalaycioglu H, Korukluoglu G, Ozkul A et al. Emergence of West Nile virus infections in humans in Turkey, 2010 to 2011. Euro Surveill. 2012;17(21):20182. 
30. Napoli C, Iannetti S, Rizzo C et al. Vector borne infections in Italy: results of the integrated surveillance system for West Nile disease in 2013. Biomed Res Int 2015;2015:643439.

31. Bassal R, Shohat $\mathrm{T}$, Kaufman $\mathrm{Z}$ et al. The seroprevalence of West Nile virus in Israel: $\mathrm{A}$ nationwide cross-sectional study. PLoS One 2017;12(6):eo179774.

32. European Centre for Disease Prevention and Control [Internet]. Epidemiological update: West Nile virus transmission season in Europe, 2017. Available from: https://ecdc.europa.eu/en/newsevents/epidemiological-update-west-nile-virus-transmission-season-europe-2017 Date of Access: October 24, 2018.

33. European Centre for Disease Prevention and Control [Internet]. Table. Transmission of West Nile fever, May to November 2017- Table of cases, 2017. Available from: https://ecdc.europa.eu/en/publications-data/table-transmission-west-nile-fever-maynovember-2017-table-cases-2017, Date of Access: October 24, 2018.

34. European Centre for Disease Prevention and Control [Internet]. Weekly updates: 2018 West Nile fever transmission season. Available from: https://ecdc.europa.eu/en/west-nilefever/surveillance-and-disease-data/disease-data-ecdc , Date of Access: October 24, 2018.

35. Napp S, Petric D, Busquets N. West Nile virus and other mosquito-borne viruses present in Eastern Europe. Pathog Glob Health. 2018;112(5):233-48.

36. Yentur Doni N, Yıldız Zeyrek F, Seyrek A, Simsek Z, Gurses G, Topluoglu S. Evaluation of epidemiological data of Malaria between 2001-2011 in Sanliurfa, Turkey. Mikrobiyol Bul 2016;50(2):307-14.

37. Aydin MF, Sahin A. Malaria epidemiology in Mersin province, Turkey from 2002 to 2011. Iran J Parasitol 2013;8(2):296-301.

38. Sarafraz S, Ghabouli Mehrabani N, Mirzaei Y et al. Epidemiology of malaria in East Azerbaijan province, Iran, from 2001 to 2013. J Parasit Dis 2016;40(3):813-7.

39. Kuscu F, Ozturk DB, Gül S, Babayigit ML. The epidemiology of Malaria in Adana between 2002 and 2012. Turkish J Parasitol 2014;38(3):147-50.

40. Ser O, Cetin H. Evaluation of Malaria cases in Antalya between 2001 and 2011. Turkish J Parasitol 2012;36(1):4-8.

41. Norouzinezhad F, Ghaffari F, Raeisi A, Norouzinejad A, Kaveh F. Malaria Four-year epidemiological trends in Sistan and Baluchistan province, Iran. Electron Physician 2017;9(1):3660-4.

42. Karadag A, Unal N, Yanık K, Borucu R, Gunaydin M, Hokelek M. Evaluating of Plasmodium species isolated from peripheral blood samples in a non-endemic region. Turkish J Parasitol 2015;39(1):5-8.

43. Fekri S, Vatandoost H, Daryanavard A et al. Malaria situation in an endemic area, Southeastern Iran. J Anthropod Borne Dis 2013;8(1):82-90. 